\title{
WUJUD DAN POLA PENALARAN NILAI KEPEDULIAN, KREATIF, DAN SOPAN SANTUN MATERI AJAR BAHASA INDONESIA DALAM BUKU SISWA KELAS VII KURIKULUM 2013
}

\author{
Liza Tri Handayani dan Laili Etika Rahmawati \\ Program Studi Pendidikan Bahasa Indonesia, \\ Fakultas Keguruan dan Ilmu Pendidikan, \\ Universitas Muhammadiyah Surakarta \\ lizatri.handayani@gmail.com, \\ Laili.Rahmawati@ums.ac.id
}

\begin{abstract}
In the last a couple of years, national character has been degraded. In the field, data showed that the morality or character of the Indonesians has now collapsed. Character education through the learning process can be very helpful. In addition to the learning process, it turns out the learning material too. We often find that in the textbook, they contain learning materials to the value of the attitude that must be followed. The purpose of this study is to describe the nature and patterns of reasoning values of caring, creative, and manners in Indonesian learning materials in class VII curriculum 2013. This research uses descriptive explanative technique. The data of this study is learning materials of text containing the value of caring, creative, and manners. Data were analyzed using data flow model of Miles and Huberman. The results showed that there were 27 form values of caring, 11 creative values, and 6 manners values in Indonesian learning materials in books class VII curriculum 2013. It was also the pattern of reasoning appropriate at this stage of the scientific approach. The pattern of reasoning realized that the process of deductive reasoning, analogy inductive, deductive analogy, the relationship between causal phenomenon, due to the cause, and 1 causal-effect 2. The new pattern appears that the causal relationship 1-induced second-result 3, and causal relationship-effects.
\end{abstract}

Keywords: values of caring, creative, manners, student book, reasoning.

\begin{abstract}
ABSTRAK
Penelitian ini bertujuan untuk mendeskripsikan wujud dan pola penalaran nilai kepedulian, kreatif, dan sopan santun materi ajar bahasa Indonesia dalam buku siswa kelas VII kurikulum 2013. Penelitian ini menggunakan jenis penelitian deskriptif eksplanatif. Data penelitian adalah materi ajar berupa teks yang mengandung nilai kepedulian, kreatif, dan sopan santun. Teknik analisis data menggunakan teknik analisis data mengalir model Miles dan Huberman. Hasil penelitian ini menunjukkan bahwa ada 27 wujud nilai kepedulian, 11 nilai kreatif, dan 6 nilai sopan santun materi ajar bahasa Indonesia dalam buku siswa kelas VII kurikulum 2013. Ditemukan juga pola penalaran sesuai pada tahap pendekatan saintifik. Pola penalaran yang terwujud yaitu proses menalar deduktif, analogi induktif, analogi deduktif, proses hubungan antar fenomena sebab-akibat, akibat-sebab, dan sebabakibat 1-akibat 2. Muncul pola baru yaitu hubungan sebab-akibat 1-akibat 2-akibat 3 dan hubungan sebab-rangkaian akibat.
\end{abstract}

Kata Kunci: nilai kepedulian, kreatif, sopan santun, buku siswa, menalar. 


\section{PENDAHULUAN}

Karakter bangsa beberapa tahun terakhir mengalami degradasi. Menanggapi hal itu dunia pendidikan terus berbenah. Suyadi (2013:1) menyatakan bahwa secara faktual data realistik menunjukkan bahwa moralitas maupun karakter bangsa saat ini telah runtuh. Kementerian Pendidikan Nasional (dalam Suyadi, 2013:2) mensinyalir bahwa sumber dari musibah yang telah meluluhlantakkan moralitas bangsa ini adalah terabaikannya pendidikan karakter. Dunia pendidikan merasa begitu bertanggung jawab terhadap penurunan moral dan karakter pada siswa. Sebagaimana dinyatakan oleh Budiningsih (2008:1) bahwa banyak orang berpandangan bahwa kondisi demikian diduga bermula dari apa yang dihasilkan oleh dunia pendidikan sehingga banyak terdengar seruan peningkatan pendidikan karakter di sekolah.

Banyak faktor yang membuat karakter siswa menurun. Salah satunya adalah sinema televisi yang tidak sesuai dengan umur dan tayang pada saat jam-jam siswa belum tidur. Faktor lain yang turut mempengaruhi hilangnya moral generasi remaja kita adalah kemajuan teknologi informasi dan komunikasi. Rasa ingin tahu yang besar pun membuat siswa terjerumus dalam hal-hal yang kurang baik. Berawal dari hal-hal itu yang kemudian menjadikan pendidikan karakter penting untuk diterapkan dalam dunia pendidikan, baik formal maupun informal dan disampaikan secara tersirat maupun tersurat dalam proses pembelajaran. Guru dituntut untuk menyisipkan nilai sikap yang baik dalam setiap kompetensi dasar yang diajarkan. Sering kali di dalam buku ajar secara eksplisit maupun implisit memuat materi pembelajaran dengan nilai sikap yang harus diteladani. Salah satunya yaitu dalam buku siswa kelas VII kurikulum 2013. Materi yang terdapat di dalam buku teks itu yang kemudian dipelajari siswa sehingga tidak hanya pengetahuan yang diperoleh, tetapi juga sikap yang membangun diri siswa. Kurikulum 2013 mendukung pencapaian kompetensi inti, yaitu kompetensi sikap spiritual (KI 1), kompetensi sikap sosial (KI 2), kompetensi pengetahuan (KI 3), dan kompetensi keterampilan (KI 4). Kompetensi yang berkenaan dengan kompetensi keagamaan dan sosial dikembangkan secara tidak langsung, yaitu pada saat siswa belajar tentang pengetahuan dan keterampilan sehingga siswa di sekolah tidak hanya belajar pengetahuan dan keterampilan, tetapi juga belajar keagamaan dan sosial tanpa mereka sadari. Berdasarkan pemikiran tersebut, peneliti tertarik untuk melakukan penelitian dengan judul "Wujud dan Pola Penalaran Nilai Kepedulian, Kreatif, dan Sopan Santun Materi Ajar Bahasa Indonesia dalam Buku Siswa Kelas VII

Kurikulum 2013.”

Berdasarkan pemaparan di atas dapat dirumuskan dua masalah: (1) bagaimana wujud nilai kepedulian, kreatif, dan sopan santun materi ajar bahasa Indonesia dalam buku siswa kelas VII kurikulum 2013 dan (2) bagaimana pola penalaran berdasarkan pendekatan saintifik nilai kepedulian, kreatif, dan sopan santun materi ajar bahasa Indonesia dalam buku siswa kelas VII kurikulum 2013. Sesuai dengan rumusan masalah, maka tujuan penelitian ini adalah untuk mendeskripsikan wujud nilai kepedulian, kreatif, dan sopan santun materi ajar bahasa Indonesia dalam buku siswa kelas VII kurikulum 2013 dan memaparkan pola penalaran berdasarkan pendekatan saintifik nilai kepedulian, kreatif, dan sopan santun materi ajar bahasa Indonesia dalam buku siswa kelas VII kurikulum 2013.

Martinez dan Martinez (2016) meneliti "Depictions of Human Bodies in the Illustrations of Early Childhood Textbooks". Temuan mereka adalah buku teks memiliki fungsi sosial dalam mensosialisasikan anak di sekolah dasar dan menengah dan membenarkan normanorma yang ada, seperti budaya, nilai, dan pengetahuan.

Segers dan Verhoeven (2016) meneliti "How Logical Reasoning Mediates the Relation between Lexical Quality and Reading Comprehension". Penelitian mereka mengangkat peran 
penalaran logis dalam hubungan antara kualitas leksikal anak-anak kelas empat di Belanda. Hasil penelitian menunjukkan bahwa kedua jenis silogisme sebagian dimediasi hubungan antara kualitas leksikal dan pemahaman bacaan. Penalaran silogisme dalam proses berpikir tingkat tinggi diperlukan untuk membuat kesimpulan dalam membaca pemahaman.

Isti'anah (2015) meneliti "Humanistic Values in English Electronic School Textbook for Senior High School". Simpulan penelitian ini menunjukkan bahwa nilai-nilai banyak dipengaruhi sikap penulis, yaitu menghormati orang lain, alam, dan isu-isu sosial. Nilai didominasi dengan menghormati orang lain sebanyak $87 \%, 73 \%$ dalam menghormati isu-isu sosial dan nilai peduli alam disajikan $71 \%$.

Anugrahwati dan Agustien (2015) meneliti "The Integration of Second Core Competence (KI 2) of Curriculum 2013 in English Classes". Hasil penelitian menunjukkan bahwa ketiga guru yang menjadi partisipan sudah mengintegrasikan pendidikan karakter saat mengajar di kelas. Namun, tidak ada strategi baru yang digunakan oleh semua guru dalam mengintegrasikan pendidikan karakter.

Hadi (2015) meneliti "The Integration of Character Values in the Teaching of Economics: A Case of Selected High Schools in Banjarmasin". Hasil penelitian ini menunjukkan bahwa guru mampu mengidentifikasi kecocokan nilai karakter untuk diintegrasikan dengan materi pelajaran, tetapi responden yang diteliti memiliki keterampilan yang terbatas, dan ragu-ragu untuk mengimplementasikan metode yang tepat dalam proses belajar mengajar. Berdasarkan hasil penemuan, dalam mengajar mata pelajaran ini disarankan menggunakan referensi mengajar dari nilai karakter, terlebih guru ekonomi di seluruh Indonesia.

Rizam (2015) meneliti "Penalaran dalam Artikel Rubrik Opini Surat Kabar Harian Jawa Pos". Simpulan penelitian ini adalah penalaran dalam artikel rubrik opini Surat Kabar Harian Jawa Pos dilakukan dalam dua varian penalaran yaitu penalaran induktif dan deduktif. Penalaran induktif terdiri dari generalisasi, analogi, dan hubungan kausal. Generalisasi dalam artikel rubrik opini tersebut berupa generalisasi dengan loncatan induktif dan tanpa loncatan induktif. Hubungan kausal berlangsung dalam tiga varian yakni sebab ke akibat, akibat ke sebab, dan akibat ke akibat. Penalaran deduktif dalam artikel rubrik opini Surat Kabar Harian Jawa Pos tidak dilakukan dalam bentuk silogisme lengkap, namun dilakukan dalam bentuk entimem.

Soleymanpour dan Kiadaliri (2014) meneliti "Analysis of Social Sciences Textbook in Fourth and Fifth Grade of Elementary Schools Based on Integrated Thinking Skills". Simpulan penelitian ini adalah temuan terhadap semua pelajaran yang bersifat sosial di dalam buku teks ilmu sosial kelas empat dan lima sekolah dasar, tingkat penerapan dan muatan komponen keterampilan berpikir untuk memperoleh informasi lebih ditekankan daripada keterampilan lainnya. Berdasarkan pengamatan dari beberapa keterampilan lain menunjukkan bahwa tidak ada koordinasi yang diperlukan untuk menerapkan kemampuan berpikir sesuai konten isi.

Hapsari (2013) meneliti “Character Education Values in Reading Section of E-English Textbook for Senior High School Students Grade XI". Simpulan penelitian ini menunjukkan adanya nilai-nilai karakter yang terintegrasi dalamketerampilan membaca e-book bahasa Inggris SMA. Dari delapan belas nilai-nilai karakter yang dirumuskan oleh Departemen Indonesia Pendidikan Nasional 2010, hanya ada tujuh belas yang tercakup dalam bagian keterampilan membaca. Satu nilai karakter yang tidak tercakup dalam bagian keterampilan membaca adalah tanggung jawab.

Iswara (2013) meneliti "Analysis of Character Education Aspects in Narrative Texts of the Electronic Textbook "Developing English Competencies"”. Simpulan penelitian ini 
menunjukkan bahwa aspek-aspek pendidikan karakter dalam teks naratif ditemukan di buku elektronik untuk siswa kelas XI. Terdapat 301 kalimat dalam teks-teks naratif yang mengandung aspek pendidikan karakter dari 605 kalimat yang ditemukan. Persentasenya mencapai 49,75\%. Kalimat yang terbagi dalam 17 teks naratif, secara relevan memuat delapan belas aspek pendidikan karakter.

Sallabas (2013) meneliti "Analysis of Narrative Texts in Secondary School Textbooks in Terms of Values Education". Simpulan penelitian ini menunjukkan bahwa teks naratif dalam buku teks dari Turki digunakan untuk pendidikan menengah. Semua teks naratif siswa dan guru yang diterbitkan oleh Departemen Pendidikan Nasional dievaluasi. Penyelidikan itu menunjukkan bahwa teks naratif dalam buku ini kaya akan nilai-nilai seperti ketekunan, kepekaan, dan cinta. Namun, nilai-nilai tertentu seperti perdamaian, toleransi, keadilan, kebebasan, kebersihan, dan kesehatan tidak termuat dalam buku ini.

Dewi (2012) meneliti "Nilai-Nilai Pendidikan Religius dalam Dongeng dalam Buku Teks Bahasa Indonesia Sekolah Menengah Pertama Kelas VII Terbitan Pusat Perbukuan Departemen Pendidikan Nasional". Simpulan penelitian ini adalah hampir semua dongeng dalam buku teks bahasa Indonesia SMP kelas VII terbitan Pusat Perbukuan Departemen Pendidikan Nasional memuat nilai pendidikan religius. Akan tetapi, ada juga dongeng yang hanya satu aspek nilai religius yang ada di dalamnya. Contohnya adalah dongeng "Empat Ekor Lembu Jantan dan Seekor Singa". Dongeng ini hanya memuat nilai pendidikan religus berupa aspek memanjatkan puji syukur. Aspek percaya akan Tuhan, tetapi tidak adanya sikap pasrah dalam dongeng.

Persamaan penelitian-penelitian sebelumnya dengan penelitian yang akan dilakukan terlihat dari sumber data yang digunakan, yaitu buku teks. Dalam hal ini penelitian yang dilakukan dikhususkan pada buku siswa kurikulum 2013 terbitan Kemendikbud. Perbedaannya terlihat pada kekhususan nilai karakter yang dicari dalam data. Selain itu, terdapat penelitian relevan yang meneliti implementasi pendidikan karakter pada RPP dan proses pembelajaran. Meskipun begitu, nilai karakter pada hakikatnya dapat diintegrasikan dalam setiap aspek pendidikan, entah itu proses pembelajaran, perangkat pembelajaran, tenaga pendidik, dan kurikulum.

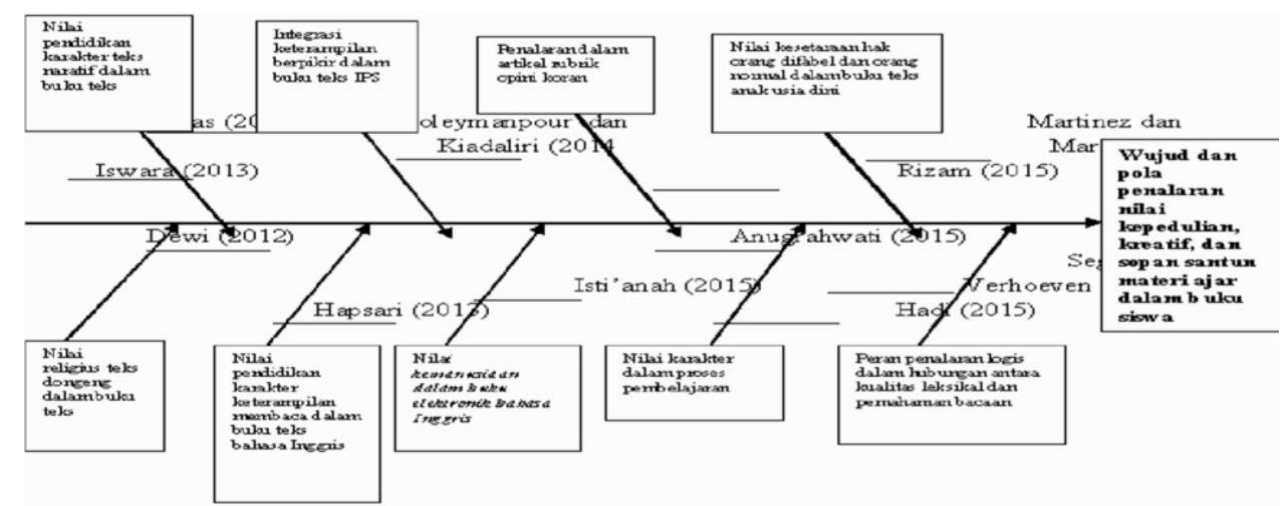

Gambar 1 Diagram fishbone penelitian relevan

Pengkajian dalam penelitian ini menggunakan beberapa teori yang saling berkaitan untuk dijadikan landasan dalam analisis dan pembahasan. Beberapa teori erat hubungannya dengan penelitian yang akan dilakukan, seperti teori mengenai buku teks dan buku siswa, materi ajar, nilai kepedulian, kreatif, sopan santun, pendidikan karakter, dan proses penalaran. Sitepu (2012:17) menyatakan bahwa buku teks pelajaran yang kemudian disebut sebagai buku teks merupakan buku acuan wajib untuk digunakan di satuan pendidikan dasar dan menengah atau 
perguruan tinggi yang memuat materi pembelajaran dalam rangka peningkatan keimanan, ketakwaan, akhlak mulia, dan kepribadian, penguasaan ilmu pengetahuan dan teknologi, peningkatan kepekaan dan kemampuan estetis, peningkatan kemampuan kinestetis dan kesehatan yang disusun berdasarkan standar nasional pendidikan.

Kemendikbud (2013:ii) menyatakan bahwa buku siswa merupakan buku yang dipersiapkan Pemerintah dalam rangka implementasi kurikulum 2013. Buku siswa menjabarkan usaha minimal yang harus dilakukan siswa untuk mencapai kompetensi yang diharapkan (Kemendikbud, 2013:iv). Buku teks maupun buku siswa memuat materi ajar. Menurut Ibrahim dan Sukmadinata (2003:100) materi pelajaran merupakan suatu yang disajikan oleh guru untuk diolah kemudian dipahami oleh siswa dalam rangka pencapaian tujuan-tujuan instruksional yang telah ditetapkan. Materi pelajaran terdiri dari fakta-fakta, generalisasi, konsep, hukum atau aturan, dan sebagainya yang terkandung dalam mata pelajaran. Gulo (2008:9) menyatakan bahwa materi pelajaran dapat dibedakan antara materi formal dan materi informal. Materi formal adalah isi pelajaran yang terdapat dalam buku teks resmi (buku paket) di sekolah, sedangkan materi informal ialah bahan-bahan pelajaran yang bersumber dari lingkungan sekolah yang bersangkutan. Bahan-bahan yang bersifat informal ini dibutuhkan agar pengajaran itu lebih relevan dan aktual.

Menurut Maksudin (2013:10) nilai adalah kualifikasi harga atau isi pesan yang dibawakan baik tersurat maupun tersirat dalam norma tersebut. Maksudin (2013:7) juga menyebutkan bahwa nilai dasar kehidupan adalah sesuatu yang dianggap berharga bagi kehidupan. Mardiatmadja (dalam Maksudin, 2013:55) juga menyatakan bahwa pendidikan nilai merupakan bantuan terhadap peserta didik agar menyadari dan mengalami nilai-nilai serta menempatkan secara integral dalam keseluruhan hidupnya. Koesoema (2011:81) mengemukakan bahwa pendidikan karakter merupakan sebuah usaha manusia untuk menjadikan dirinya sebagai manusia yang berkeutamaan.

Listyarti (2014:7) membagi nilai peduli menjadi dua, yaitu nilai peduli lingkungan dan sosial. Peduli lingkungan yang merupakan sikap dan tindakan yang selalu berupaya mencegah kerusakan pada lingkungan alam sekitarnya, dan mengembangkan upaya-upaya untuk memperbaiki kerusakan alam yang sudah terjadi. Sedangkan peduli sosial merupakan sikap dan tindakan yang selalu ingin memberi bantuan pada orang lain dan masyarakat yang membutuhkan. Ciri-ciri nilai peduli menurut Hidayatullah (2010:86) yaitu menaruh perhatian atau minat terhadap sesuaatu, menghiraukan, dan memperhatikan. Selanjutnya, Listyarti (2014:6) menyatakan bahwa kreatif merupakan berpikir dan melakukan sesuatu untuk menghasilkan cara atau hasil baru dari sesuatu yang telah dimiliki. Ciri-ciri kreatif menurut Hidayatullah (2010:84) adalah mendekati sebuah kebutuhan, tugas atau ide dari suatu perspektif yang baru, kualitas pemikiran yang orisinil, menghasilkan; menyebabkan ada, dan imajinasi; kemampuan membayangkan. Hidayatullah (2010:86) menyatakan bahwa sopan merupakan suatu sikap hormat dan takdzim, serta tertib menurut adat yang baik. Ciri-ciri sopan adalah beradab mengenai perilaku, tutur kata, pakaian, baik budi bahasanya serta tahu adat, baik perangai dan kelakuannya (tidak cabul atau tidak lacur). Hidayatullah (2010:85) juga menyatakan bahwa santun merupakan suatu sikap yang halus dan baik dilihat dari budi bahasanya maupun tingkah lakunya. Ciri-ciri santun yaitu sabar dan tenang, penuh rasa belas kasihan, suka menolong.

Jalaluddin (2013:109) menyatakan bahwa penalaran berarti berpikir dengan menggunakan nalar atau rasio. Sebagaimana dinyatakan oleh Suriasumantri (2010:42) bahwa penalaran merupakan suatu proses berpikir dalam menarik sesuatu kesimpulan yang berupa pengetahuan, sehingga penalaran merupakan kegiatan berpikir yang mempunyai karakteristik tertentu dalam menemukan kebenaran. Menurut Kurniasih dan Sani (2014:35) ada beberapa proses menalar, yaitu: proses menalar induktif yang merupakan cara menalar dengan menarik 
simpulan dari fenomena atau atribut-atribut khusus untuk hal-hal yang bersifat umum. Menalar induktif adalah proses penarikan simpulan dari kasus-kasus yang bersifat nyata secara individual atau spesifik menjadi simpulan yang bersifat umum. Kegiatan menalar secara induktif lebih banyak berpijak pada observasi inderawi atau pengalaman empirik. Proses menalar deduktif yang merupakan cara menalar dengan menarik simpulan dari pernyataan-pernyataan atau fenomena yang bersifat umum menuju pada hal yang bersifat khusus.

Suriasumantri (2010:46) menyatakan bahwa logika atau penalaran induktif erat hubungannya dengan penarikan kesimpulan dari kasus-kasus individual nyata menjadi kesimpulan yang bersifat umum. Adapun di pihak lain logika deduktif membantu dalam menarik simpulan dari hal yang bersifat umum menjadi kasus yang bersifat individual (khusus). Menurut Kurniasih dan Sani (2014:38-39) proses analogi terdiri dari dua jenis, yaitu analogi induktif dan analogi deduktif. Analogi induktif disusun berdasarkan persamaan yang ada pada dua fenomena atau gejala. Analogi deduktif merupakan suatu metode menalar untuk menjelaskan atau menegaskan suatu fenomena atau gejala yang belum dikenal atau masih samar, dengan sesuatu yang sudah dikenal atau masih samar, dan dengan sesuatu yang sudah dikenal. Lain halnya dengan Jalaluddin yang menyebut analogi sebagai analisis. Menurut Jalaluddin (2013:115) analisis induktif merupakan perumusan umum mengenai suatu gejala dengan cara mempelajari kejadian-kejadian khusus yang berhubungan dengan hal itu. Analisis deduktif dinyatakan sebagai analisis yang digunakan untuk menetapkan kebenaran suatu pernyataan dengan menunjuk bahwa pernyataan lain yang telah ditetapkan kebenarannya. Penalaran juga dapat dilakukan melalui proses hubungan antar fenomena, sebagaimana yang dinyatakan oleh Kurniasih dan Sani (2014:39-40) terdiri dari hubungan sebab-akibat, hubungan akibat-sebab, dan hubungan sebab-akibat 1 - akibat 2 .

\section{METODE PENELITIAN}

Jenis dan desain penelitian yang digunakan pada penelitian ini adalah penelitian deskriptif kualitatif yang bersifat eksplanatif yang bertujuan untuk menggambarkan dan menjelaskan. Peneliti memberikan deskripsi mengenai wujud dan pola penalaran nilai karakter yang ada dalam buku siswa kelas VII. Kemudian memberikan eksplanasi (kejelasan) tentang proses identifikasi wujud dan pola penalaran nilai karakter (nilai kepedulian, kreatif, dan sopan santun) materi ajar bahasa Indonesia dalam buku siswa kelas VII kurikulum 2013.

Data penelitian ini adalah semua materi ajar yaitu berupa teks yang mengandung nilai kepedulian, kreatif, dan sopan santun dalam buku siswa kelas VII kurikulum 2013. Sumber data yang digunakan untuk mendapatkan data-data tersebut adalah buku siswa kelas VII kurikulum 2013. Teknik pengumpulan data yang digunakan dalam penelitian ini adalah dokumentasi atau analisis dokumen, yaitu dokumen buku siswa kelas VII kurikulum 2013. Dokumen yang diteliti pada penelitian ini merupakan dokumen resmi yang dikeluarkan oleh Kemendikbud yaitu buku siswa kelas VII kurikulum 2013.

Analisis data menggunakan analisis data mengalir model Miles dan Huberman. Menurut Sugiyono (2010:337) analisis data dalam penelitian kualitatif dilakukan pada saat pengumpulan data berlangsung dan setelah selesai pengumpulan data dalam periode tertentu. Analisis data kualitatif dilakukan secara mengalir dan berlangsung terus menerus sampai tuntas hingga data bersifat jenuh. Aktivitas dalam analisis data, yaitu data reduction, data display, dan conclusion drawing/verification.

Setelah pengumpulan data, dilakukan antisipasi sebelum melakukan reduksi data (sering tanpa sadar) yaitu dengan kerangka konsep, keadaan sebenarnya, pertanyaan penelitian, dan data yang telah dikumpulkan. 
Untuk menguji validitas data, digunakan trianggulasi data dan teori. Trianggulasi data atau sumber dilakukan dengan peninjauan ulang terhadap data atau sumber, yaitu meninjau ulang mengenai kesesuaian data yang digunakan, yakni data materi ajar yang berupa teks dalam buku siswa kelas VII kurikulum 2013. Pada trianggulasi teori dilakukan dengan peninjauan ulang terhadap teori-teori relevan yang digunakan dalam penelitian ini sehingga ada kesesuaian antara teori dan data yang digunakan.

\section{HASIL DAN PEMBAHASAN}

Wujud nilai karakter banyak ditemukan dalam teks materi ajar buku siswa kelas VII kurikulum 2013. Setiap teks materi ajar memiliki beragam karakter, bahkan dalam satu paragraf mampu memuat dua sampai tiga nilai karakter yang diimplisitkan dalam pemerolehan pengetahuan dan keterampilan. Sebagaimana konsep kurikulum 2013 bahwa penanaman sikap spiritual dan sosial dikembangkan secara tidak langsung pada saat siswa belajar pengetahuan maupun keterampilan sehingga adanya relevansi antara konsep kurikulum 2013 dengan pengembangan nilai karakter yang diwujudkan melalui sikap sosial dan sikap spiritual dalam KI 1 dan 2.

Tabel 1. Muatan Nilai Karakter dalam Setiap Teks Materi Ajar

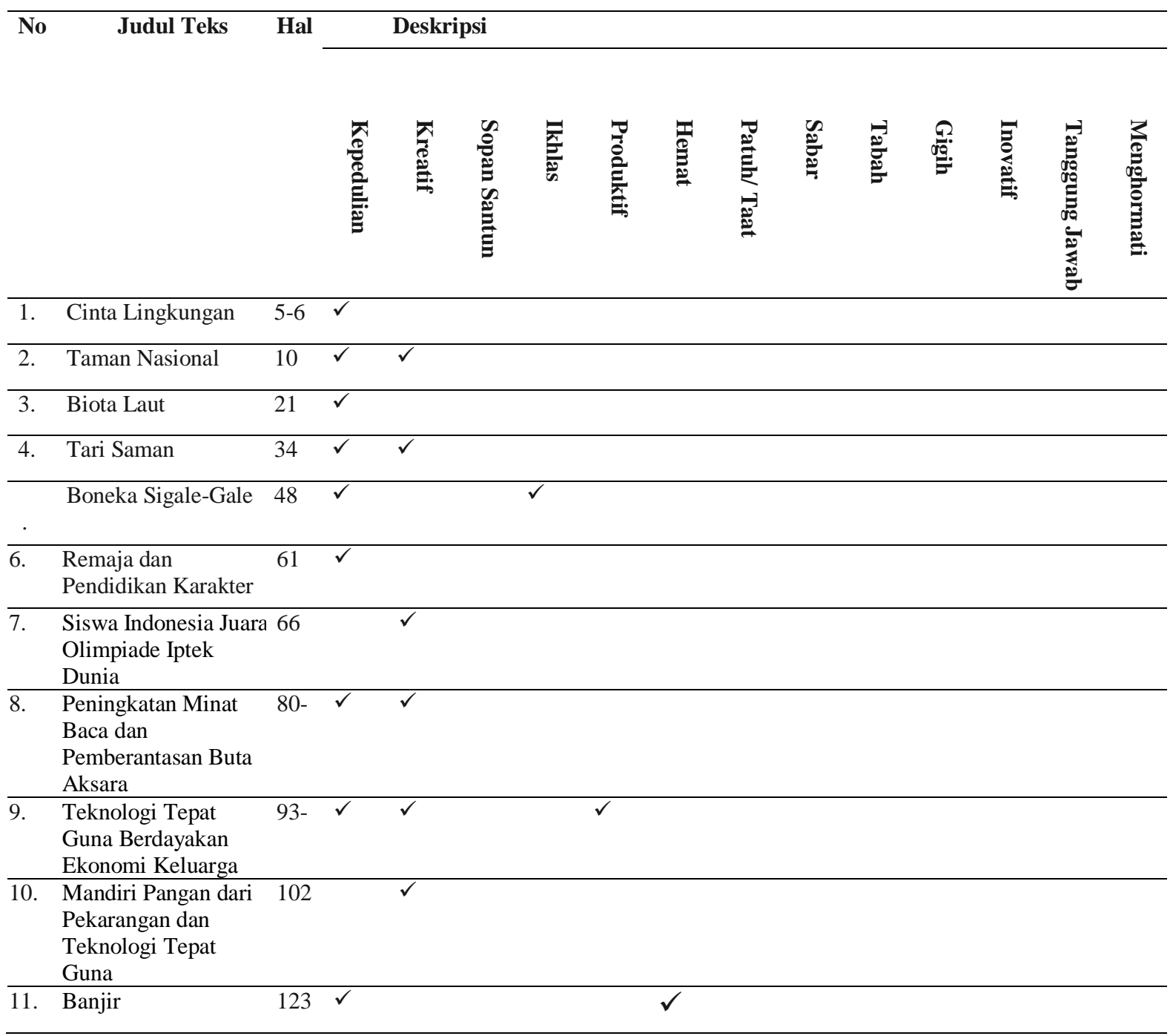




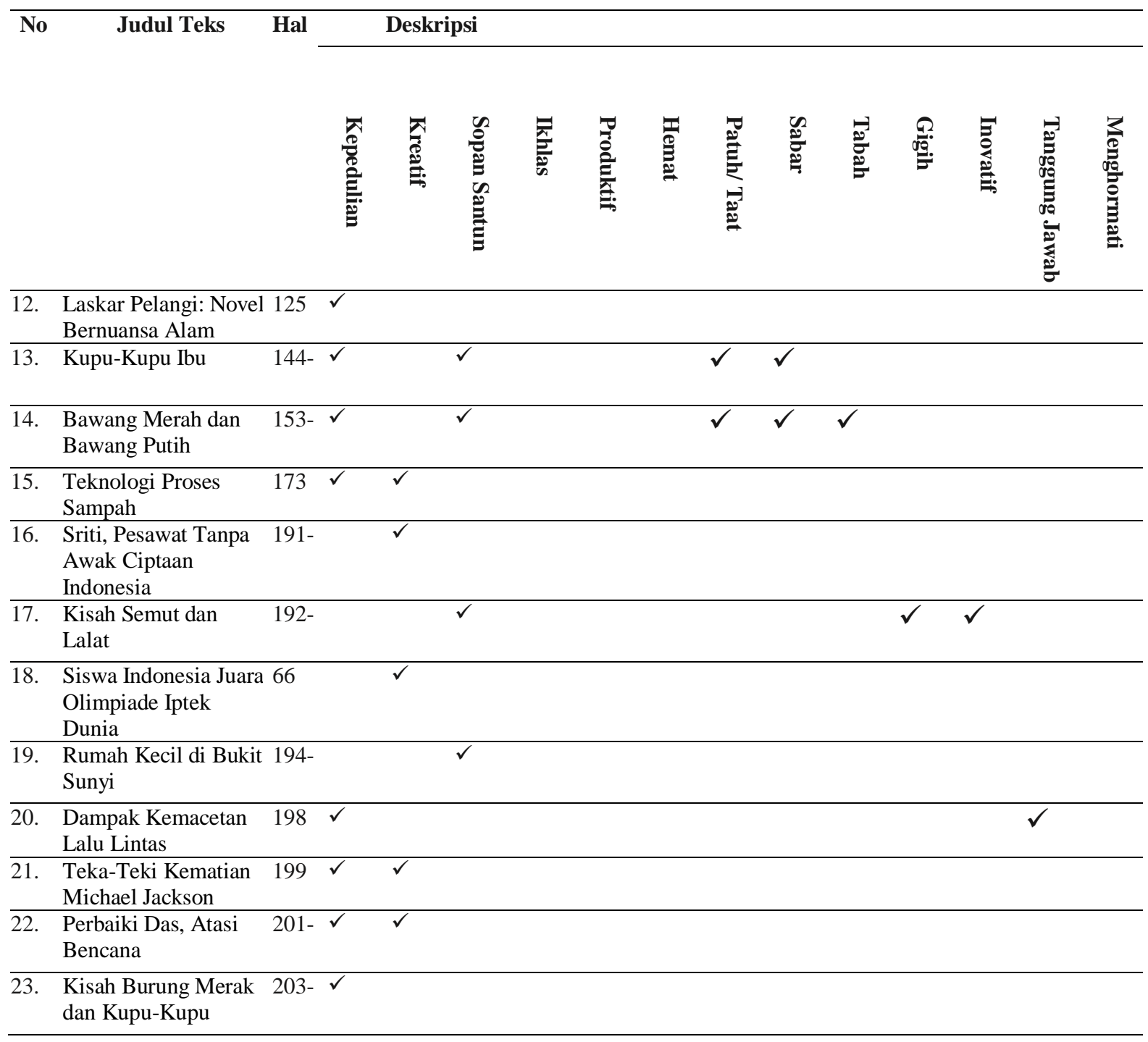

Beberapa nilai karakter selain nilai kepedulian, kreatif, dan sopan santun termuat dalam teks materi ajar, yaitu nilai ikhlas, produktif, hemat, patuh atau taat, sabar, tabah, gigih, inovatif, tanggung jawab, dan menghormati orang lain. Namun, kuantitas yang lebih banyak ditemukan adalah nilai kepedulian, kreatif, dan sopan santun. Ada 13 nilai karakter yang terwujud dalam 23 teks materi ajar. Fokus kajian penelitian hanya dalam nilai kepedulian, kreatif, dan sopan santun. Ketiga nilai tersebut lebih banyak muncul dan dibutuhkan oleh siswa usia sekolah menengah pertama atau SMP.

Proses analisis berdasarkan rumusan masalah pertama yang telah ditentukan menunjukkan adanya suatu nilai karakter kepedulian, kreatif, dan sopan santun materi ajar dalam buku siswa kelas VII kurikulum 2013. Dalam satu buku ada 44 penggalan teks materi ajar yang mengandung nilai kepedulian, kreatif, dan sopan santun. Empat puluh empat penggalan teks materi ajar disajikan dalam bentuk teks laporan hasil observasi, teks tanggapan deskriptif, teks eksposisi, teks ekplanasi, dan teks cerita pendek. Nilai kepedulian paling banyak ditemukan di antara tiga nilai karakter yang diidentifikasi dan dianalisis. Rumusan masalah kedua menunjukkan adanya pola penalaran berdasarkan pendekatan saintifik nilai kepedulian, kreatif, dan sopan santun materi ajar bahasa Indonesia dalam buku siswa kelas VII kurikulum 2013. 


\section{Wujud Nilai Kepedulian Materi Ajar Bahasa Indonesia dalam Buku Siswa Kelas VII Kurikulum 2013}

\begin{tabular}{ll}
\hline No & \multicolumn{1}{c}{ Data } \\
\hline 1) & $\begin{array}{l}\text { Jika terpelihara dengan baik, lingkungan hidup itu dapat menciptakan masyarakat yang sehat, aman, } \\
\text { tenteram, lahir, dan batin (Kemendikbud, 2013:5-6). }\end{array}$ \\
2) & $\begin{array}{l}\text { Melihat rajanya sakit, para tetua adat pun berusaha mengobati Raja Rahat agar sembuh kembali } \\
\text { (Kemendikbud, 2013:48). }\end{array}$ \\
3) & $\begin{array}{l}\text { Tari Saman tercatat di UNESCO pada Daftar Representatif Budaya Takbenda Warisan Manusia } \\
\text { (Kemendikbud, 2013:21). }\end{array}$ \\
T) & $\begin{array}{l}\text { Teknologi Tepat Guna (TTG) dapat juga digunakan untuk menggali potensi suatu wilayah untuk } \\
\text { meningkatkan ekonomi masyarakatnya. TTG dapat menjadi sarana untuk menciptakan peluang kerja }\end{array}$ \\
\hline
\end{tabular}

Nilai kepedulian ditunjukkan pada teks materi ajar melalui kalimat atau paragraf yang mengandung minat dan perhatian terhadap sesuatu, memperhatikan sesuatu, dan menghiraukannya. Listyarti (2014:7) membagi nilai peduli menjadi dua, yaitu nilai peduli lingkungan dan sosial. Peduli lingkungan ditandai dengan sikap dan tindakan pencegahan terhadap perusakan lingkungan dan peduli sosial ditunjukkan melalui sikap maupun tindakan yang ingin membantu orang lain. Terdapat 27 wujud nilai kepedulian materi ajar dalam buku siswa kelas VII kurikulum 2013.

Nilai kepedulian terwujud dalam penggalan teks laporan hasil observasi. Kepedulian terhadap lingkungan yaitu memperhatikan dan menaruh minat terhadap pemeliharaan lingkungan agar tercipta keseimbangan hidup. Tindakan ingin merawat menjadi suatu bentuk kepedulian, tidak hanya memperhatikan dan menaruh minat, tetapi juga melakukan aksi atau tindakan yang merupakan wujud nyata dari sebuah sikap kepedulian terhadap lingkungan. Tujuan kepedulian lingkungan yang dilakukan cukup beragam. Salah satunya agar lingkungan yang dilestarikan tetap menjadi sumber kekayaan hayati dan warisan kekayaan alam itu mampu memberikan kontribusi baik berupa hasil yang dapat dinikmati berupa hasil hutan, sawah, dan laut maupun upaya pengembangkan potensi wisata untuk menarik wisatawan dan menambah pendapatan negara.

Wujud nilai kepedulian sosial ditunjukkan melalui upaya-upaya atau tindakan dalam melakukan kegiatan dan sikap sosial. Kepedulian sosial disajikan dalam wujud yang beraneka ragam, yaitu dalam bentuk sosial-ekonomi dalam data 4 , sosial budaya dalam data 3 , dan sosial kemasyarakatan dalam data 2 sesuai penggalan teks yang memuat nilai kepedulian. Berdasarkan teks materi ajar dalam buku siswa kelas VII, sebagian besar wujud nilai kepedulian lingkungan hanya berupa sikap dan belum diwujudkan dalam bentuk tindakan, seperti pada data 1 .

\section{Wujud Nilai Kreatif}

\begin{tabular}{|c|c|}
\hline No & Data \\
\hline 1) & $\begin{array}{l}\text { Pada awalnya Tari Saman merupakan salah satu media untuk menyampaikan pesan (dakwah). Tari } \\
\text { Saman mengandung pendidikan keagamaan, sopan santun, kepahlawanan, kekompakan, dan } \\
\text { kebersamaan (Kemendikbud, 2013:34). }\end{array}$ \\
\hline 2) & $\begin{array}{l}\text { Penelitian yang mereka lakukan adalah mengelola limbah hewan yang terdapat pada kulit udang dan } \\
\text { kepiting yang mengandung bahan antibakteri. Kedua siswa itu secara kreatif memanfaatkannya untuk } \\
\text { industri garmen (Kemendikbud, 2013:66). }\end{array}$ \\
\hline 3) & $\begin{array}{l}\text { Media itu harus dimanfaatkan masyarakat untuk meningkatkan pengetahuan (Kemendikbud, } \\
\text { 2013:80). }\end{array}$ \\
\hline
\end{tabular}


Terdapat 11 nilai kreatif dari penggalan teks materi ajar dalam buku siswa kelas VII kurikulum 2013. Nilai-nilai kreatif tersebut diimplisitkan dalam teks laporan hasil observasi, teks tanggapan deskriptif, dan teks eksposisi. Menurut Hidayatullah (2010:84) ciri-ciri kreatif yaitu suatu ide dari suatu perspektif baru, pemikiran yang orisinal, kemampuan untuk menghasilkan, dan imajinasi atau kemampuan membayangkan sehingga kreatif cukup beragam bentuknya, dapat berupa ide, perwujudan atau suatu hasil karya maupun produk, dan kualitas menghasilkan sesuatu yang unik.

Nilai kreatif diwujudkan teks materi ajar dalam buku siswa kelas VII kurikulum 2013 melalui data 2. Penggalan teks eksposisi tersebut merupakan perwujudan dari nilai kreatif. Melalui kalimat yang dipaparkan, dapat diketahui bahwa kreativitas muncul dari ide dalam suatu sudut pandang yang baru, kulit udang yang kurang bermanfaat kemudian dilihat melalui sudut pandang yang berbeda, dinyatakan bahwa dapat bermanfaat untuk industri garmen, karena kandungan bahan antibakteri dalam kulit udang. Melalui ide yang muncul setelah memandang kulit udang dari sudut lain, kemudian muncul suatu tindakan untuk memanfaatkan kulit-kulit udang yang kurang bermanfaat tersebut menjadi bahan penunjang proses industri besar garmen. Proses kreatif sering kali menghasilkan hal-hal unik yang semula kurang bermanfaat menjadi sangat bermanfaat.

Nilai kreatif dari penggalan-penggalan teks materi ajar tersebut memiliki muatan dan bentuk nilai kreatif yang berbeda. Data 1 memuat nilai kreatif dalam penggalan teks yaitu adanya ide untuk menyampaikan dakwah melalui tarian. Lain halnya dengan data 2 yang menghasilkan karya atau produk nyata sehingga bermanfaat dan mampu mengembangkan dunia ilmu pengetahuan. Data 3 memuat ide mengenai pemanfaatan media dan teknologi untuk membantu dan menghasilkan sesuatu yang lebih bermanfaat.

\section{Wujud Nilai Sopan Santun}

\begin{tabular}{|c|c|}
\hline No & Data \\
\hline 1) & Tiba-tiba pintu terbuka dan laki-laki dengan perut gendut muncul (Kemendikbud, 2014:194-195). \\
\hline 2) & $\begin{array}{l}\text { Aku lebih suka sendiri. Aku tak mau merepotkanmu. Karena suatu saat kau mungkin akan menemui } \\
\text { kesulitan hanya karena keberadaanku (Kemendikbud, 2013:146). }\end{array}$ \\
\hline 3) & $\begin{array}{l}\text { Saat itu anak pemilik rumah keluar dan tidak menutup kembali pintu rumah. Kemudian, seekor lalat } \\
\text { bergegas terbang memasuki rumah itu. Si lalat langsung menuju meja makan yang penuh dengan } \\
\text { makanan lezat (Kemendikbud, 2013:192). }\end{array}$ \\
\hline
\end{tabular}

Wujud nilai sopan santun materi ajar dalam buku siswa kelas VII hanya terdapat dalam teks cerita pendek, dalam hal ini adalah naskah sastra. Nilai sopan santun sebagaimana dinyatakan Hidayatullah (2010:85-86) bahwa sopan santun adalah sikap hormat dan tertib terhadap adat yang baik, halus, dan baik dilihat dari budi bahasa dan tingkah laku. Sopan santun mencerminkan suatu sikap seseorang, sehingga penerapan dalam suatu teks selain teks cerita pendek kurang dapat diimplementasikan. Nilai sopan santun berhubungan langsung dengan sikap manusia dan sering dijumpai dalam teks yang berbentuk naratif, sehingga wujud nilai sopan santun materi ajar dalam buku siswa kelas VII ini hanya ada dalam teks cerita pendek.

Salah satu wujud penggalan teks cerita pendek yang mengandung nilai sopan santun adalah data 1, dilihat dari segi kalimat, penggalan teks cerita pendek ini bukan sebuah wujud nilai sopan santun karena tidak mencerminkan budi baik sebagaimana adat bertamu harus mengetuk pintu terlebih dahulu. Akan tetapi, sering dijumpai bahwa amanat dalam suatu cerita, dalam hal ini adalah teks cerita pendek, wujud nilai sopan santun harus ditafsirkan oleh 
siswa saat membaca teks tersebut. Penggalan teks cerita pendek data 1 memuat ketidaksopanan dalam bertamu. Akan tetapi, penulis justru ingin menyampaikan bahwa nilai sopan santun harus diterapkan dalam bertamu, wujud seperti ini merupakan wujud implisit, wujud nilai sopan santun seperti ini harus membutuhkan penalaran dari siswa. Sama halnya dengan data 3, wujud sopan santun justru ditunjukkan melalui suatu ketidaksopanan yang dilakukan oleh lalat yang memasuki rumah seseorang tanpa izin.

Nilai karakter yang termuat dalam teks materi ajar buku siswa kelas VII kurikulum 2013 sebagai salah satu upaya pendukung dalam implementasi kurikulum 2013. Terwujudnya beragam nilai karakter dalam buku siswa menunjukkan adanya suatu sikap dan tindakan yang dijadikan sebagai bahan belajar siswa dan diintegrasikan dalam pembelajaran berbasis karakter. Nilai kepedulian, kreatif, dan sopan santun menjadi salah satu contoh bahwa buku siswa layak untuk dijadikan sebagai bahan ajar. Selain itu, buku siswa mampu menunjang implementasi kurikulum 2013 dalam penanaman karakter, terutama nilai kepedulian, kreatif, dan sopan santun.

\section{Pola Menalar Deduktif Berdasarkan Pendekatan Saintifik Nilai Kepedulian, Kreatif, dan Sopan Santun Materi Ajar Bahasa Indonesia dalam Buku Siswa Kelas VII Kurikulum 2013}

\begin{tabular}{ll}
\hline No & \multicolumn{1}{c}{ Data } \\
\hline & $\begin{array}{l}\text { Biota laut adalah seluruh makhluk hidup yang berkembang biak di laut. Biota laut yang ada di } \\
\text { perairan Indonesia merupakan salah satu kekayaan Indonesia yang sangat berlimpah. Biota laut itu di } \\
\text { antaranya terumbu karang, ikan, dan tumbuh-tumbuhan laut yang menjadi bagian dari ekosistem laut } \\
\text { ( Kemendikbud, 2013:21). }\end{array}$ \\
\hline & $\begin{array}{l}\text { Persoalannya adalah sebagian masyarakat belum menyadari pentingnya teknologi pengolahan } \\
\text { sampah. Sekarang bergantung pada masyarakat apakah menjadikan sampah sebagai bahan yang } \\
\text { kotor, berbau, menjijikkan, atau menjadikan sampah sebagai bahan yang bermanfaat bagi kehidupan } \\
\text { (Kemendikbud, 2013:173). }\end{array}$ \\
& $\begin{array}{l}\text { Pesawat tersebut merupakan salah satu pesawat yang digunakan dalam dunia militer yang berfungsi } \\
\text { sebagai pesawat pengintai. Tak hanya itu, fungsi pesawat ini juga digunakan untuk kegiatan } \\
\text { memantau hutan, pencurian ikan, atau memantau aktivitas gunung berapi yang dipantau dari atas } \\
\text { (Kemendikbud, 2013:191). }\end{array}$ \\
\hline
\end{tabular}

Pola menalar deduktif hanya ada tiga data yang ditemukan dari beberapa teks yang dianalisis. Seperti yang dinyatakan Suriasumantri (2010:46) bahwa logika deduktif membantu dalam menarik kesimpulan dari hal yang bersifat umum menjadi kasus yang bersifat individual (khusus). Penggalan kalimat tersebut menunjukkan adanya pernyataan-pernyataan atau fenomena yang bersifat umum "Biota laut adalah seluruh makhluk hidup yang berkembang biak di laut" menuju pada hal yang bersifat khusus "Biota laut yang ada di perairan Indonesia merupakan salah satu kekayaan Indonesia yang sangat berlimpah. Biota laut itu di antaranya terumbu karang, ikan, dan tumbuh-tumbuhan laut yang menjadi bagian dari ekosistem laut". Pola proses menalar deduktif diawali dengan pemaparan peryataan umum menuju pada fenomena yang bersifat khusus. Proses menalar dengan menggunakan penalaran deduktif hanya ada tiga pola. Jika dibandingkan dengan temuan pola penalaran lainnya, pola menalar deduktif lebih sedikit. Karena data yang digunakan hanya kalimat dan paragraf sehingga proses menalar deduktif jarang ditemukan. Sebenarnya membutuhkan beberapa paragraf untuk dapat menentukan pola melalui proses menalar deduktif. Sama dengan proses menalar induktif yang juga membutuhkan kalimat yang panjang atau beberapa paragraf untuk menentukan pola menalar yang digunakan. Bahkan, dari beberapa teks materi 
ajar yang dianalisis, tidak ada muatan nilai karakter dalam kalimat atau paragraf yang memiliki pola menalar induktif.

\section{Pola Proses Analogi Induktif}

\begin{tabular}{|c|c|}
\hline No & Data \\
\hline 1) & $\begin{array}{l}\text { Pengagum Jacko itu mengaku mendapat literatur permodelan matematika yang dapat menghitung } \\
\text { dosis obat dalam darah. Awalnya, penelitian Oki hanya bisa menjelaskan efek samping Demerol } \\
\text { yang dikonsumsi Jacko. Akan tetapi, kemudian dia mendapat rumus aman untuk menghitung dosis } \\
\text { obat yang wajar dikonsumsi dalam darah (Kemendikbud, 2013:199). }\end{array}$ \\
\hline 2) & $\begin{array}{l}\text { Oki berharap dirinya dapat menjadi ilmuwan muda yang mewakili Indonesia dalam Internasional } \\
\text { Conference Young Scientist ke-17 serta dapat mengharumkan nama bangsa (Kemendikbud, } \\
\text { 2013:199). }\end{array}$ \\
\hline 3) & $\begin{array}{l}\text { Ning, aku tak ingin orang-orang akan ikut bergunjing tentangmu, hanya karena kau menemuiku } \\
\text { di sini. Aku tak mau orang menjauhimu, bila mereka tahu kau pernah datang mengunjungiku } \\
\text { (Kemendikbud, 2013:146). }\end{array}$ \\
\hline 4) & $\begin{array}{l}\text { Karya ini diterjemahkan ke dalam beberapa bahasa. Di Amerika misalnya, terjemahan novel ini } \\
\text { sudah terjual lebih dari } 4.000 \text { eksemplar. Filmnya juga mendapat sambutan hangat di luar negeri, di } \\
\text { antaranya saat film ini diputar di Festival Berlin (Kemendikbud, 2013:125). }\end{array}$ \\
\hline
\end{tabular}

Menurut Jalaluddin (2013:115) analogi induktif atau analisis induktif sebagai sebuah perumusan umum mengenai suatu gejala dengan cara mempelajari kejadian-kejadian khusus yang berhubungan dengan hal itu. Seperti pada contoh data 1, analisis induktif dilakukan dengan cara mempelajari rangkaian kegiatan khusus yang menyangkut proses pelaksanaan penelitian. Mulai dari peneliti mendapat literatur permodelan matematika yang dapat menghitung dosis obat dalam darah. Selanjutnya, fakta bahwa penelitian hanya menjelaskan efek samping Demerol yang dikonsumsi Jacko, sampai pada mendapatkan rumus aman untuk menghitung dosis obat yang wajar dikonsumsi dalam darah. Untuk menyimpulkan faktor penyebabnya didukung oleh analisis deduktif. Analisis deduktif didasarkan pada kebenaran pernyataan yang sudah ada atau pernyataan yang berdasarkan teori. Dalam penggalan teks yang dijadikan data, penggalan kalimat lainnya memuat beberapa kalimat dengan sejumlah informasi bahwa uji karya ilmiah tentang kematian tragis penyanyi legendaris itu dalam perhitungan matematika sehingga dapat diperoleh perumusan umum bahwa berdasarkan perhitungan matematika itu dapat disimpulkan bahwa penyebab kematian Michael Jackson lebih kuat disebabkan karena overdosis. Gejala-gejala khusus yang ada dalam analisis induktif merupakan langkah-langkah yang dilakukan untuk menemukan rumus baru dan mendapatkan hasil penelitian yang lebih baik. Dengan memadukan antara induktif (data lapangan) dan deduktif (teoretis), proses analisis atau analogi dalam upaya menarik kesimpulan menjadi lebih akurat (Jalaluddin, 2013:116). Dengan demikian, proses analogi induktif atau bisa juga disebut sebagai analisis induktif adalah gejala-gejala khusus yang saling berhubungan untuk merumuskan suatu gejala secara umum yang didasarkan pada data-data di lapangan.

Sama dengan data-data yang lainnya, seperti pada data 4 yang merupakan paparan gejalagejala khusus untuk mendapatkan perumusan umum mengenai karya Andrea Hirata yang mendapat sambutan hangat dari luar negeri, baik novel maupun film Laskar Pelangi. Gejalagejala khusus yang ada dalam penggalan teks eksplanasi tersebut yang pertama "Karya ini diterjemahkan ke dalam beberapa bahasa. Di Amerika misalnya, terjemahan novel ini sudah terjual lebih dari 4.000 eksemplar" dan fenomena kedua yaitu "Filmnya juga mendapat sambutan hangat di luar negeri, di antaranya saat film ini diputar di Festival Berlin". Kedua fenomena tersebut memiliki persamaan yaitu seperti pada paparan perumusan umum mengenai adanya suatu penerimaan yang baik suatu karya di negara lain. 


\section{Pola Proses Analogi Deduktif}

\begin{tabular}{|c|c|}
\hline No & Data \\
\hline 1) & $\begin{array}{l}\text { Keunikan yang dimiliki Sriti yaitu tak adanya roda untuk lepas landas atau mendarat. Namun, untuk } \\
\text { lepas landas pesawat ini menggunakan catapult take off yaitu sejenis peluncur yang terbuat dari } \\
\text { logam baja stainless yang cukup fleksibel karena bisa dibongkar pasang kapan pun. Untuk mendarat, } \\
\text { pesawat ini menggunakan jaring yang bersifat lentur dan berbahan kuat. Kelebihan unik lainnya dapat } \\
\text { dibawa kemana-mana karena Sriti dapat dibongkar pasang (Kemendikbud, 2013:192). }\end{array}$ \\
\hline 2) & $\begin{array}{l}\text { Dengan teknologi yang tepat, sampah yang tadinya sebagai barang buangan, kotor, berbau, } \\
\text { menimbulkan penyakit, dan mencemari lingkungan dapat menjadi barang yang bisa dimanfaatkan dan } \\
\text { memiliki nilai ekonomi tinggi. Sampah anorganik bisa membantu mengembangkan industri daur } \\
\text { ulang (recycling), sedangkan sampah organik dapat dimanfaatkan industri pengolah kompos menjadi } \\
\text { pupuk organik dan juga dapat diolah menjadi industri energi atau industri bahan bangunan } \\
\text { (Kemendikbud, 2013:173). }\end{array}$ \\
\hline 3) & $\begin{array}{l}\text { Pada awalnya Tari Saman merupakan salah satu media untuk menyampaikan pesan (dakwah). Tari } \\
\text { Saman mengandung pendidikan keagamaan, sopan santun, kepahlawanan, kekompakan, dan } \\
\text { kebersamaan (Kemendikbud, 2013:34). }\end{array}$ \\
\hline
\end{tabular}

Analisis deduktif digunakan untuk menetapkan kebenaran suatu pernyataan dengan menunjuk bahwa pernyataan itu telah tercakup dalam pernyataan lain yang telah ditetapkan kebenarannya (Jalaluddin, 2013:115). Sehingga, ada proses menjelaskan suatu gejala yang masih sulit diidentifikasi melalui gejala yang sudah dikenal atau sudah diketahui kebenarannya. Pada contoh beberapa data terdapat juga beberapa gejala yang masing-masing memiliki suatu gejala yang masih samar atau belum mampu diidentifikasi. Data 3 menjelaskan gejala yang masih samar yaitu "Pada awalnya Tari Saman merupakan salah satu media untuk menyampaikan pesan (dakwah)", dalam hal ini dakwah belum dijelaskan kebenaran dakwah seperti apa yang akan disampaikan. Kemudian menjadi lebih tegas dan jelas melalui gejala yang didasarkan pada kebenaran pernyataan bahwa pesan yang sebenarnya ingin disampaikan melalui gejala "Tari Saman mengandung pendidikan keagamaan, sopan santun, kepahlawanan, kekompakan, dan kebersamaan”.

Pola analisis deduktif yang digunakan cukup beragam dan tersebar dalam beberapa teks yang ada dalam buku siswa kelas VII kurikulum 2013. Sering kali penggunaannya tidak secara berurutan, sedangkan data yang digunakan adalah kalimat atau paragraf yang disusun secara sistematis dan berurutan, maka tidak heran jika pola analisis deduktif yang ditemukan dalam bentuk kalimat sistematis hanya sedikit. Tidak menutup kemungkinan jika seluruh teks menggunakan pola analisis ini. Sama halnya dengan data 1 dan data 2 keduanya juga memuat gejala yang masih samar yang kemudian dijelaskan dengan gejala yang telah ditetapkan kebenarannya. Tampak pada data 2 bahwa gejala masih samar mengenai nilai ekonomi tinggi yang tampak pada kalimat "Dengan teknologi yang tepat, sampah yang tadinya sebagai barang buangan, kotor, berbau, menimbulkan penyakit, dan mencemari lingkungan dapat menjadi barang yang bisa dimanfaatkan dan memiliki nilai ekonomi tinggi”, dijelaskan dan dihubungkan dengan gejala yang nyata dan kebenarannya teruji, yaitu pada penggalan kalimat "Sampah anorganik bisa membantu mengembangkan industri daur ulang (recycling), sedangkan sampah organik dapat dimanfaatkan industri pengolah kompos menjadi pupuk organik dan juga dapat diolah menjadi industri energi atau industri bahan bangunan". Penjelasan tersebut mampu menjelaskan mengenai peluang mendapatkan nilai ekonomi dari sampah yang semula masih samar. 


\section{Pola Proses Hubungan Antarfenomena Sebab-Akibat}

\begin{tabular}{ll}
\hline No & \multicolumn{1}{c}{ Data } \\
\hline & $\begin{array}{l}\text { Remaja adalah masa transisi dari masa anak-anak ke masa awal dewasa. Usia remaja berada pada } \\
\text { kisaran usia } 10 \text { tahun sampai dengan } 21 \text { tahun. Pada masa itu remaja sedang mencari identitas } \\
\text { dirinya. Oleh karena itu, remaja harus mendapatkan pendidikan karakter agar dapat mengarahkan } \\
\text { minatnya pada kegiatan-kegiatan positif (Kemendikbud, 2013:61-62). }\end{array}$ \\
\hline & $\begin{array}{l}\text { Sejak Ibu Bawang Putih meninggal, Ibu Bawang Merah kerap berkunjung ke tempat tinggal Bawang } \\
\text { Putih. Dia kerap membawakan makanan, menolong Bawang Putih membereskan tempat tinggal atau } \\
\text { cuma menemani Bawang Putih serta ayahnya mengobrol (Kemendikbud, 2013:153). }\end{array}$ \\
& $\begin{array}{l}\text { Dengan demikian, akibat kemacetan lalu lintas pun muncul, seperti waktu yang terbuang percuma. } \\
\text { Selain itu, bahan bakar juga terbuang percuma. Kemacetan lalu lintas juga dapat menyebabkan } \\
\text { polusi udara dan suara. Bahkan, dapat mengakibatkan stress yang menyerang kesehatan rohani kita } \\
\text { (Kemendikbud, 2013:198). }\end{array}$ \\
\hline
\end{tabular}

Hubungan sebab-akibat menurut Kurniasih dan Sani (2014:39) adalah hal-hal yang mengemukakan sebab terlebih dahulu, kemudian ditarik simpulan yang berupa akibat. Pola hubungan sebab-akibat adalah pola yang sering muncul dan digunakan dalam pola penalaran beragam teks materi ajar dalam buku siswa kurikulum 2013. Pola sebab-akibat lebih mudah diidentifikasi jika dibandingkan dengan pola yang lain.

Beberapa contoh pola sebab-akibat dalam suatu teks yaitu pada data 1,2 , dan 3 . Data 1 semula dipaparkan sebuah sebab, yaitu "Remaja adalah masa transisi dari masa anak-anak ke masa awal dewasa. Usia remaja berada pada kisaran usia 10 tahun sampai dengan 21 tahun. Pada masa itu remaja sedang mencari identitas dirinya." Selanjutnya, disimpulkan pola itu berupa akibat yaitu "Oleh karena itu, remaja harus mendapatkan pendidikan karakter agar dapat mengarahkan minatnya pada kegiatan-kegiatan positif." masa remaja adalah masa yang kritis dan berusaha mencari jati diri, sehingga akibat yang ditimbulkan dari sebab itu adalah perlunya pendidikan karakter yang mampu mengarahkan remaja menuju arah positif. Sama halnya dengan data 2 , hal yang menjadi sebab pada penggalan teks cerita pendek tersebut adalah "Sejak Ibu Bawang Putih meninggal", kemudian ditarik kesimpulan yang berupa akibat yaitu "Ibu Bawang Merah kerap berkunjung ke tempat tinggal Bawang Putih. Dia kerap membawakan makanan, menolong Bawang Putih membereskan tempat tinggal atau cuma menemani Bawang Puth serta ayahnya mengobrol" sehingga keduanya memiliki hubungan penalaran sebab-akibat. Ibu Bawang Putih yang sudah meninggal menjadi sebab Ibu Bawang Merah terus berkunjung ke rumah Bawang Putih. Data 3, polanya yaitu sebab diungkapkan terlebih dahulu, kemudian akibat mengikuti di belakang sehingga simpulan yang ada menjadi masuk akal karena ada proses mengenai akibat itu sendiri yaitu dengan didahului sebab.

\section{Pola Proses Hubungan Antarfenomena Akibat-Sebab}

\begin{tabular}{ll}
\hline No & \multicolumn{1}{c}{ Data } \\
\hline 1) & $\begin{array}{l}\text { Aku lebih suka sendiri. Aku tak mau merepotkanmu. Karena suatu saat kau mungkin akan menemui } \\
\text { kesulitan hanya karena keberadaanku (Kemendikbud, 2013:146). }\end{array}$ \\
\hline 2) & $\begin{array}{l}\text { Penelitian yang mereka lakukan adalah mengelola limbah hewan yang terdapat pada kulit udang dan } \\
\text { kepiting yang mengandung bahan anti bakteri. Kedua siswa itu secara kreatif memanfaatkannya } \\
\text { untuk industri garmen (Kemendikbud, 2013:66). }\end{array}$ \\
\hline 3) & $\begin{array}{l}\text { Tiba-tiba pintu terbuka dan laki-laki dengan perut gendut muncul. "Ooo.... Juragan. Silakan, Gan”, } \\
\text { sambut Pak Kerto sambil membungkuk (Kemendikbud, 2013:194). }\end{array}$ \\
\hline
\end{tabular}


Pola proses hubungan antar fenomena akibat-sebab merupakan kebalikan dari pola hubungan sebab-akibat sehingga dalam pola hubungan ini akibat dipaparkan terlebih dahulu, kemudian sebab mengikuti di belakang. Tidak ada kekhususan dari pola ini terhadap pola sebab-akibat karena hanya seperti bertukar posisi, sehingga tidak ada perbedaan khusus dari keduanya. Pola akibat-sebab tidak banyak ditemukan seperti pola sebab-akibat. Sebagaimana dalam suatu teks yang biasanya justru didominasi oleh proses menalar deduktif dibandingkan dengan induktif. Pola akibat-sebab tampak pada data 1, 2, dan 3.

Akibat yang dikemukakan pada data 1 adalah "Aku lebih suka sendiri. Aku tak mau merepotkanmu", penyebab dari akibat tersebut yang kemudian menjadi simpulan yaitu "Karena suatu saat kau mungkin akan menemui kesulitan hanya karena keberadaanku". Sama halnya dengan data 2 akibat dinyatakan terlebih dahulu yaitu "Penelitian yang mereka lakukan adalah mengelola limbah hewan yang terdapat pada kulit udang dan kepiting yang mengandung bahan anti bakteri". Mengelola limbah hewan sebagai akibat dari kreativitas kedua siswa untuk memanfaatkan limbah yang berguna bagi industri garmen, simpulan yang menjadi penyebab, yaitu "Kedua siswa itu secara kreatif memanfaatkannya untuk industri garmen". Data 3 fenomena yang menjadi akibat diungkapkan pada kalimat "Tiba-tiba pintu terbuka", penyebab pintu terbuka ternyata diungkapkan melalui kalimat "laki-laki dengan perut gendut muncul, "Ooo... Juragan. Silakan, Gan", sambut Pak Kerto sambil membungkuk". Jika dibandingkan dengan pola lainnya, baik pola proses menalar maupun analogi, pola hubungan antar fenomena lebih mudah digunakan, karena proses penalarannya tidak begitu rumit, sehingga siswa lebih mudah apabila menemukan teks dengan menggunakan pola penalaran akibat-sebab, sebabakibat, maupun sebab-akibat 1-akibat 2 . Begitu pula data 2 yang sama-sama membentuk rangkaian hubungan antarfenomena sebabakibat 1-akibat 2.

\section{Pola Proses Hubungan Antarfenomena Sebab-Akibat 1-Akibat 2}

\begin{tabular}{ll}
\hline No & \multicolumn{1}{c}{ Data } \\
\hline & Alam yang indah harus dicintai, dijaga, dan dilestarikan. Kecintaan pada alam itu harus selalu kita \\
tumbuhkan kepada seluruh warga Indonesia. Selain itu, rasa cinta itu juga harus terus ditanamkan agar \\
alam Indonesia tetap menjadi paru-paru dunia yang bermanfaat bagi kehidupan seluruh makhluk \\
hidup yang hidup dari masa ke masa (Kemendikbud, 2013:5-6). \\
Meredam erosi pada lahan pertanian terbuka dapat dilakukan dengan menutup tanah dengan plastik \\
berlubang. Dengan demikian, air hujan tidak langsung menggerus tanah. Tanah yang tidak ditanami \\
bisa ditutup dengan rumput dan semak atau perdu yang relatif cepat pertumbuhannya (Kemendikbud, \\
2013:201). \\
Nenek itu menyimpan baju Bawang Putih yang hanyut. Dia mau menyerahkan baju itu jika Bawang \\
3) Putih mau membantunya membersihkan rumah. Bawang Putih pun segera membantu nenek \\
membersihkan rumah (Kemendikbud, 2013:153).
\end{tabular}

Proses hubungan antarfenomena sebab-akibat 1-akibat 2 adalah penyebab yang ada mampu menimbulkan serangkaian akibat, akibat pertama kemudian menjadi penyebab dari akibat kedua, bahkan akibat kedua menjadi penyebab dari akibat ketiga, dan seterusnya (Kurniasih dan Sani, 2014:40). Pola seperti ini muncul pada kalimat atau paragraf yang panjang. Namun, tidak menutup kemungkinan ditemukan juga dalam kalimat atau paragraf yang pendek. Seperti pada data 3, satu penyebab yang menimbulkan rangkaian akibat adalah "Nenek itu menyimpan baju Bawang Putih yang hanyut", dari penyebab tersebut muncul akibat 1 yaitu "Dia mau menyerahkan baju itu jika Bawang Putih mau membantunya membersihkan rumah", akibat 1 menjadi penyebab akibat 2. Akibat kedua yaitu "Bawang 
Putih pun segera membantu nenek membersihkan rumah". Ketiganya saling membentuk serangkaian akibat. Sama halnya dengan data 1, yang menjadi penyebab pada penggalan teks tersebut adalah "Alam yang indah harus dicintai, dijaga, dan dilestarikan. Kecintaan pada alam itu harus selalu kita tumbuhkan kepada seluruh warga Indonesia. Selain itu, rasa cinta itu juga harus terus ditanamkan". Akibat yang pertama yaitu "Alam Indonesia tetap menjadi paru-paru dunia", yang kemudian menjadi penyebab dari akibat kedua "yang bermanfaat bagi kehidupan seluruh makhluk hidup yang hidup dari masa ke masa”.

\section{a. Pola Proses Hubungan Antarfenomena Sebab-Akibat 1-Akibat 2-Akibat 3}

\begin{tabular}{cl}
\hline No & Data \\
\hline & Tak jauh dari tempat kejadian, segerombolan Ulat Bulu melihat kejadian ini. Melihat kondisi burung \\
merak yang tidak berdaya Ulat Bulu pun membantu Burung Merak untuk dibebaskan dan mereka \\
pun menyerang si pemburu, akibat serangan tersebut, si pemburu lari tunggang langgang tidak kuat \\
terhadap gatal-gatal yang diterimanya dan Burung Merak pun bebas (Kemendikbud, 2013:203). \\
Teknologi daur ulang (recycling) dapat dimanfaatkan untuk mengolah sampah menjadi barang jadi \\
yang bisa dimanfaatkan dalam kehidupan sehari-hari. Sampah dipungut dan dikumpulkan, misalnya, \\
kertas, kardus, pecahan kaca, botol bekas, logam-logam, plastik, dan sebagainya. Barang-barang \\
bekas ini bisa dikirim ke pabrik yang melakukan daur ulang bisa diolah menjadi bahan baku. Bahan \\
baku itu dapat menghasilkan produk daur ulang seperti karton, kardus pembungkus, alat-alat dan \\
perangkat rumah tangga dari plastik dan kaca (Kemendikbud, 2013:176).
\end{tabular}

Selain proses hubungan antarfenomena sebab-akibat 1-akibat 2, ternyata juga ditemukan pola baru, yaitu hubungan antarfenomena sebab-akibat 1-akibat 2-akibat 3 dan hubungan sebabrangkaian akibat. Jika hubungan antarfenomena sebab-akibat 1-akibat 2 adalah penyebab yang ada mampu menimbulkan serangkaian akibat, akibat pertama kemudian menjadi penyebab dari akibat kedua. Maka, hubungan antarfenomena sebab-akibat 1-akibat 2akibat 3 ada sebuah akibat kedua yang menjadi penyebab dari akibat ketiga, dan seterusnya (Kurniasih dan Sani, 2014:40). Seperti dalam data 1, sebab dari penggalan teks cerita pendek tersebut adalah "Tak jauh dari tempat kejadian, segerombolan Ulat Bulu melihat kejadian ini”. Setelah itu, sebab tersebut menimbulkan serangkaian akibat. Akibat pertama yang menjadi penyebab dari akibat kedua adalah "Ulat Bulu pun membantu Burung Merak untuk dibebaskan dan mereka pun menyerang si pemburu", akibat kedua yang menjadi penyebab akibat ketiga adalah "si pemburu lari tunggang langgang tidak kuat terhadap gatal-gatal yang diterimanya", dan akibat terakhir adalah "Burung Merak pun bebas". Berdasarkan temuan pola hubungan antarfenomena ini, tidak menutup kemungkinan dalam suatu kalimat atau paragraf memuat 4 rangkaian sebabakibat atau lebih.

\section{b. Pola Proses Hubungan Antarfenomena Sebab-Rangkaian Akibat}

\begin{tabular}{ll}
\hline No & \multicolumn{1}{c}{ Data } \\
\hline 1$)$ & Alam yang indah harus dicintai, dijaga, dan dilestarikan. Kecintaan pada alam itu harus selalu kita \\
& tumbuhkan kepada seluruh warga Indonesia. Selain itu, rasa cinta itu juga harus terus ditanamkan \\
& agar alam Indonesia tetap menjadi paru-paru dunia yang bermanfaat bagi kehidupan seluruh makhluk \\
& hidup yang hidup dari masa ke masa (Kemendikbud, 2013:5-6). \\
\hline 2) & Dengan membaca buku, kita akan memperoleh pengetahuan. Oleh sebab itu, membaca dapat \\
& memperbaiki kehidupan. Untuk itu, usaha peningkatan minat baca dan pemberantasan buta aksara ini \\
& perlu didukung terus sehingga taraf hidup masyarakat akan meningkat (Kemendikbud, 2013:80-81). \\
\hline 3) & $\begin{array}{l}\text { Dengan demikian, akibat kemacetan lalu lintas pun muncul, seperti waktu yang terbuang percuma. } \\
\text { Selain itu, bahan bakar juga terbuang percuma. Kemacetan lalu lintas juga dapat menyebabkan polusi }\end{array}$ \\
& udara dan suara. Bahkan, dapat mengakibatkan stress yang menyerang kesehatan rohani kita \\
& (Kemendikbud, 2013:198).
\end{tabular}


Data 2 memuat penyebab "Dengan membaca buku" dan menimbulkan rangkaian akibat. Ada tiga akibat yang disebabkan karena membaca buku. Akibat pertama "kita akan memperoleh pengetahuan", akibat kedua "membaca dapat memperbaiki kehidupan", akibat ketiga "usaha peningkatan minat baca dan pemberantasan buta aksara ini perlu didukung terus sehingga taraf hidup masyarakat akan meningkat". Berdasarkan temuan pola hubungan antarfenomena ini, tidak menutup kemungkinan dalam suatu kalimat atau paragraf memuat akibat yang ditimbulkan oleh satu sebab.

Data 1 "Alam yang indah harus dicintai, dijaga, dan dilestarikan. Kecintaan pada alam itu harus selalu kita tumbuhkan kepada seluruh warga Indonesia. Selain itu, rasa cinta itu juga harus terus ditanamkan". Akibat yang pertama yaitu "Alam Indonesia menjadi paru-paru dunia", akibat lainnya "yang bermanfaat bagi kehidupan seluruh makhluk hidup yang hidup dari masa ke masa"sebab dalam data 3 "akibat kemacetan lalu lintas pun muncul", kemudian akibat yang ditimbulkan dari kemacetan lalu lintas itu adalah "seperti waktu yang terbuang percuma", "bahan bakar juga terbuang percuma", "polusi udara dan suara", dan "stress yang menyerang kesehatan rohani kita".

Pola penalaran berdasarkan pendekatan saintifik nilai kepedulian, kreatif, dan sopan santun materi ajar dalam buku siswa kelas VII kurikulum 2013 menggunakan berbagai macam pola yang ada. Di antaranya adalah pola menalar deduktif, analogi induktif, analogi deduktif, hubungan antar fenomena sebab-akibat, hubungan antar fenomena akibat-sebab, dan hubungan antar fenomena sebab-akibat 1-akibat 2. Bahkan ditemukan pola baru yaitu proses hubungan antar fenomena sebab-akibat 1-akibat 2-akibat 3. Proses penalaran itu sendiri merupakan suatu proses berpikir dalam menarik suatu kesimpulan yang berupa pengetahuan (Fautanu, 2012:60). Pola menalar yang harus dilakukan siswa cukup beragam untuk memahami nilai kepedulian, kreatif, dan sopan santun, siswa harus melakukan proses menalar sesuai dengan pendekatan saintifik atau pendekatan ilmiah yang menjadi konsep kurikulum 2013. Proses menalar tidak hanya mengasosiasikan peristiwa-peristiwa khusus saja, tetapi juga menyatukan pengalaman dengan pikiran sehingga dapat berpikir logis sesuai fakta yang ada di lapangan.

Beberapa penelitian terdahulu menjadi dasar dilakukannya penelitian ini. Terdapat beberapa persamaan dan perbedaan antara penelitian yang dilakukan dengan penelitian terdahulu. Hasil penelitian Martinez dan Martinez (2016) memiliki persamaan dengan penelitian yang dilakukan yaitu sama-sama mengungkapkan nilai karakter yang ada dalam suatu buku teks yang digunakan siswa untuk belajar. Penelitian yang dilakukan oleh Martinez ini merupakan penelitian yang mengungkapkan buku teks ECE Kolombia memuat keseimbangan yang baik antara kesetaraan anak laki-laki dan perempuan, yaitu menghormati hak-hak anak perempuan di dalam pendidikan yang berkualitas. Sama halnya dengan mengungkapkan nilai persamaan hak laki-laki dan perempuan. Sedangkan penelitian yang dilakukan mengungkapkan nilai kepedulian, kreatif, dan sopan santun melalui teks materi ajar yang disajikan. Penelitian Martinez menunjukkan adanya pertimbangan bahwa buku teks adalah kendaraan untuk norma-norma, nilai-nilai, dan model sosial perilaku. Sama halnya dengan buku siswa yang berperan sebagai sarana untuk menyalurkan ranah afektif ke dalam teks materi ajar secara implisit. Perbedaannya terletak dari nilai yang ingin disampaikan bahwa dalam buku teks ECE Kolumbia tidak memuat tentang difabel, hal ini menjadikan buku teks ECE sebagai penghalang atau suatu bentuk pengucilan.

Hasil penelitian Segers dan Verhoeven (2016) memiliki persamaan dengan penelitian yang akan dilakukan yaitu sama-sama mengungkapkan penalaran. Hasil penelitian Segers dan Verhoeven menunjukkan bahwa silogisme sebagian dimediasi hubungan antara kualitas leksikal dan pemahaman bacaan. Penalaran silogisme dalam proses berpikir tingkat tinggi diperlukan untuk membuat kesimpulan dalam membaca pemahaman. Penelitian yang 
dilakukan berdasarkan rumusan masalah kedua juga mengungkapkan wujud penalaran, dalam hal ini silogisme biasa juga disebut sebagai penalaran deduktif. Perbedaannya temuan penelitian yang dilakukan hanya sebatas menunjukkan wujud penalaran, tetapi penelitian Segers dan Verhoeven menunjukkan keterkaitan kualitas leksikal, penalaran silogisme dan pemahaman bacaan.

Hasil penelitian Penelitian Isti'anah (2015) memiliki persamaan dengan penelitian yang dilakukan yaitu mengungkapkan wujud nilai dalam suatu buku teks. Nilai yang sangat ditonjolkan adalah nilai kemanusiaan tentang menghormati orang lain, sama dengan nilai kepedulian yang diwujudkan dalam buku siswa kelas VII bahwa kepedulian termasuk nilai kemanusiaan. Perbedaan kedua penelitian ini terletak di dalam pemaparan nilai yang ada dalam suatu buku teks, yang diaparkan di dalam penelitian Isti'anah adalah nilai dominan yang ada dalam buku elektronik. Adapun penelitian yang dilakukan memberi pembatasan hanya pada wujud nilai kepedulian, kreatif, dan sopan santun, meskipun paling banyak ditemukan adalah nilai kepedulian.

Hasil penelitian Anugrahwati dan Agustien (2015) memiliki persamaan dengan penelitian yang dilakukan yaitu adanya paparan integrasi nilai-nilai karakter dalam suatu pembelajaran. Namun, terdapat beberapa perbedaan, pengintegrasian nilai karakter dalam penelitian Anugrahwati dan Agustien ditunjukkan melalui partisipan tiga guru yang mengungkapkan kompetensi sikap sosial (KI 2) dalam proses belajar-mengajar, sedangkan nilai karakter penelitian yang dilakukan ada dalam buku siswa kelas VII kurikulum 2013.

Hasil penelitian Rizam (2015) memiliki persamaan penelitian ini dengan penelitian yang dilakukan adalah menunjukkan pola penalaran yang digunakan dalam suatu teks. Penelitian Rizam memaparkan bahwa penalaran dalam artikel rubrik opini surat kabar harian Jawa Pos dilakukan dalam dua varian penalaran yaitu penalaran induktif dan deduktif. Perbedaannya terlihat dalam penggunaan pola penalaran dalam teks materi ajar buku siswa kelas VII kurikulum 2013 lebih beragam, di dalam rubrik opini koran Jawa Pos hanya dua pola saja. Bahkan ada pengembangan pola baru dalam hubungan antarfenomena.

Beberapa teks yang dianalisis adalah sebuah keutuhan penguasaan sikap, pengetahuan, dan keterampilan. Masing-masing teks memiliki muatan nilai karakter yang harus diteladani siswa dan disampaikan secara eksplisit, implisit, maupun bentuk negasi dari nilai karakter yang ingin diwujudkan. Bahkan keseluruhan teks yang sangat minim dengan teori membuat siswa berusaha tahu apa yang artinya penerapan ranah pengetahuan ada dalam teks dan menganalisis teks yang disajikan, baik mengenai teori yang berupa definisi teks, struktur teks, dan memahami isi setiap teks sehingga paham terhadap perbedaan masing-masing teks. Selain itu implementasi ranah keterampilan sangat terlihat melalui proses mencoba. Siswa dituntut mampu menyusun teks baik secara berkelompok maupun individu. Bahkan beberapa teks sesuai petunjuk kerja, siswa dituntut mengubah suatu teks ke dalam bentuk lain.

\section{SIMPULAN}

Berdasarkan paparan data dan hasil penelitian, ditemukan 27 wujud nilai kepedulian, 11 nilai kreatif, dan 6 nilai sopan santun materi ajar bahasa Indonesia dalam buku siswa kelas VII kurikulum 2013. Ketiga nilai karakter tersebut dipaparkan dalam bentuk penggalan kalimat dan paragraf materi ajar berupa teks, yaitu teks laporan hasil observasi, teks tanggapan deskriptif, teks eksposisi, teks eksplanasi, dan teks cerita pendek. Nilai kepedulian, kreatif, dan sopan santun yang ada dalam buku siswa kelas VII merupakan bentuk pengembangan bahan ajar bermuatan karakter sebagai implementasi kurikulum 2013. Hal ini juga sebagai upaya untuk mengintegrasikan kompetensi sikap sosial sesuai dengan KI 2 yang dikembangkan secara tidak langsung pada saat siswa belajar pengetahuan dan keterampilan. 
Selain wujud nilai karakter, ditemukan juga pola penalaran sesuai pada tahap pendekatan saintifik. Pola penalaran yang terwujud dari paparan nilai kepedulian, kreatif, dan sopan santun yaitu proses menalar deduktif, analogi atau analisis induktif, analogi deduktif, proses hubungan antar fenomena sebab-akibat, akibat-sebab, dan sebab-akibat 1-akibat 2. Bahkan ditemukan pola baru yaitu hubungan sebab-akibat 1-akibat 2-akibat 3, dan hubungan sebabrangkaian akibat yang merupakan pengembangan dari hubungan sebab-akibat. Hasil penelitian dengan mendeskripsikan wujud dan pola penalaran nilai kepedulian, kreatif, dan sopan santun materi ajar dalam buku siswa kelas VII kurikulum 2013 menunjukkan bahwa buku siswa terbitan Kemendikbud layak untuk dijadikan bahan ajar. Buku siswa telah memenuhi konsep kurikulum 2013 yaitu pembelajaran berbasis karakter. Selain itu, termuat integrasi pengembangan tiga ranah sikap, pengetahuan, dan keterampilan.

\section{DAFTAR PUSTAKA}

Anugrahwati, Yulia dan Helena I. R. Agustien. 2015. The Integration of Second Core Competence (KI 2) of Curriculum 2013 in English Classes. Journal of English Language Teaching, Vol. 4 No 1: 1-8.

Budiningsih, C. Asri. 2008. Pembelajaran Moral: Berpijak pada Karakteristik Siswa dan Budayanya. Jakarta: Rineka Cipta.

Dewi. Yusra. 2012. "Nilai-Nilai Pendidikan Religius dalam Dongeng dalam Buku Teks Bahasa Indonesia Sekolah Menengah Pertama Kelas VII Terbitan Pusat Perbukuan Departemen Pendidikan Nasional”. Jurnal Pena, Vol. 2 No 2: 71-83.

Fautanu, Idzam. 2012. Filsafat Ilmu: Teori dan Aplikasi. Jakarta: Anggota IKAPI.

Gulo, W. 2008. Strategi Belajar Mengajar. Jakarta: Grasindo.

Hadi, Rizali. 2015. "The Integration of Character Values in The Teaching of Economics: A Case of Selected High Schools in Banjarmasin”. International Education Studies, Vol. 8 No 7: 11-20.

Hapsari, Pratama Lysa. 2013. "Character Education Values in Reading Section of E-English Textbook for Senior High School Students Grade XI”. English Language Teaching Forum, Vol. 2 No 1: 1-6.

Ibrahim, R dan Nana Syaodih Sukmadinata. 2003. Perencanaan Pengajaran. Jakarta: Rineka Cipta.

Isti'anah, Arina. 2015. "Humanistic Values In English Electronic School Textbook For Senior High School". Language Circle Journal of Language and Literature, Vol. 10 No 1: 7383.

Iswara, Ratna Widya. 2013. "Analysis of Character Education Aspects in Narrative Texts of the Electronic Textbook: Developing English Competencies". Journal of English Language Teaching, Vol. 2 No 2: 1-9. 
Jalaluddin. 2013. Filsafat Ilmu Pengetahuan. Jakarta: Rajawali Pers.

Kementerian Pendidikan dan Kebudayaan. 2013. Bahasa Indonesia: Wahana Pengetahuan. Jakarta: Kementerian Pendidikan dan Kebudayaan.

Kurniasih, Imas dan Berlin Sani. 2014. Panduan Membuat Bahan Ajar Buku Teks Pelajaran Sesuai dengan Kurikulum 2013. Surabaya: Kata Pena.

Listyarti, Retno. 2014. Pendidikan Karakter dalam Metode Aktif, Inovatif, dan Kreatif. Jakarta: Erlangga.

Mahmud, H. 2011. Metode Penelitian Pendidikan. Bandung: Pustaka Setia.

Maksudin. 2013. Pendidikan Karakter Non-Dikotomik. Yogyakarta: Pustaka Pelajar.

Martınez-Bello, Vladimir E. dan Daniel A. Martınez-Bello. 2016. "Depictions of Human Bodies in the Illustrations of Early Childhood Textbooks". Early Childhood Education Journal, Vol. 44 No 2: 181-190.

Rizam, Masyithah Maghfirah. 2015. "Penalaran dalam Artikel Rubrik Opini Surat Kabar Harian Jawa Pos". Kembara, Vol. 1 No 2: 205-211.

Sallabas, Muhammed Eyyup. 2013. "Analysis of Narrative Texts in Secondary School Textbooks in Terms of Values Education". Educational Research and Reviews, Vol. 8 No 8: 361-366.

Segers, Eliane dan Ludo Verhoeven. 2016. "How Logical Reasoning Mediates The Relation Between Lexical Quality and Reading Comprehension". Reading and Writing Journal, Vol. 29 No 4: 577-590.

Sitepu, B.P. 2012. Penulisan Buku Teks Pelajaran. Bandung: Remaja Rosdakarya.

Soleymanpour, Javad dan Servin Kiadaliri. 2014. "Analysis of Social Sciences Textbook in Fourth and Fifth Grade of Elementary Schools Based on Integrated Thinking Skills".

Arabian Journal of Business and Management Review (Oman Chapter), Vol. 4 No 5: 1322.

Sugiyono. 2010. Metode Penelitian Pendidikan: Pendekatan Kuantitatif, Kualitatif, dan R\&D. Bandung: Alfabeta.

Sukmadinata, Nana Syaodih. 2015. Metode Penelitian Pendidikan. Bandung: Remaja Rosdakarya.

Suriasumantri, Jujun S. 2010. Filsafat Ilmu: Sebuah Pengantar Populer. Jakarta: Pustaka Sinar Harapan.

Suyadi. 2013. Strategi Pembelajaran Pendidikan Karakter. Bandung: Remaja Rosdakarya. 